\title{
The impact of energy fuel choice determinants on sustainable energy consumption of selected South African households
}

\author{
Benedict Belobo Ateba ${ }^{1,2^{*}}$, Johannes Jurgens Prinsloo², Erika Fourie ${ }^{3}$ \\ 1 Management Sciences/ School of Business and Governance, North West University, Private Bag X2046, \\ Mafikeng 2745, South Africa \\ 2 Business Management/School of Business and Governance, North West University, Private Bag X2046, \\ Mafikeng 2745, South Africa \\ ${ }^{3}$ Natural and Agricultural sciences/ Unit for Business Mathematics and Informatics North West University, \\ Private Bag X6001, Potchefstroom 2520, South Africa
}

\begin{abstract}
The erratic nature of electricity supply in South Africa combines with other factors continuous to affect household electricity demand, leading to increasing reliance on other fuels. This dependence is characterised by the use of traditional fuels by mostly low-income households, contributing significantly to environmentally harmful emissions. This study assessed the primary determinants of energy fuel choice in selected South African households, to alert policymakers to important energy consumption behavioural tendencies that can inform policies and that can assist sustainable energy growth and reduction of biomass use in households. The investigation was primarily based on energy consumption models and used a quantitative research design. Gauteng and North West were considered for data collection. Households, in general, tended to practice energy stacking. The results suggest policy measures that could promote sustainable energy use by households.
\end{abstract}

Journal of Energy in Southern Africa 29(3): 51-65

DOI: http://dx.doi.org/10.17159/2413-3051/2018/v29i3a4714

Published by the Energy Research Centre, University of Cape Town ISSN: 2413-3051 http://journals.assaf.org.za/jesa

Sponsored by the Department of Science and Technology

\footnotetext{
* Corresponding author: Tel: +27 (0)73 690 2154; email:

atebabenedict@yahoo.com
} 


\section{Introduction}

Andrew (2015:1) asserted that the most important need in life is the availability of energy to drive social development and industrial competitiveness. Elias and Victor (2005:4) argued that human behaviour has been changing constantly towards the utilisation of energy because of the influence of technological developments. However, despite the need for improved access to sustainable energy, Ellingsen (2010:3) stated that there is still a constant growth in energy inequality, as most rural households across the world continue to struggle to access modern energy services, leading to increasing reliance on traditional biofuels. Pachauri and Rao (2014:1) highlighted that energy inequality was commonly analysed on the following bases:

- income or some related monetary measure, as prevailing disparities in income would closely mirror inequalities in energy accessed and consumed; and

- disparities in energy quantities consumed and types of energy sources predominantly used.

The authors argued that the distribution of modern energy sources remained highly unequal, with a much higher dependence on environmentally unfriendly energy fuels by most people, especially in developing countries. A massive study conducted by the International Energy Agency (IEA) (2006:40) on households' use of biofuels, reflected the following findings;

- over 2.5 billion people around the world still primarily rely on traditional energy sources such as fuelwood, charcoal, agricultural and animal waste to meet their daily energy demand for cooking and heating yearly. A total of 1.6 billion people are still without complete electricity access;

- in developing countries over $90 \%$ of most household daily energy consumption comes from biofuels; and

- one-third of the world's population (2.7 billion people) will still primarily depend on biofuels in 2030.

Oparinde (2010:3) found that biomass fuels could be regarded as combustible renewables such as vegetable materials that can be converted into vegetable oil, landfill gas and bio-additives. Biomass can also be traditional energy fuels such as wood and animal waste, and intermediate biomass sources such as charcoal and coal. Biomass use in the present study was taken to refer to traditional energy fuels. Gallachóir (2007) recommended that energy research was primary for developing robust policies and initiating a change towards increased energy sustainability. Such empirical research significantly contributes to understanding energy poverty in South Africa. The IEA (2002:376) found that only $23 \%$ of the sub-Saharan population is electrified, with about 500 million people still unconnected to an electricity source, making the least electrified region in the world. Winkler (2006:34) cited recent estimates showing that a significant proportion of South Africa's households would remain unelectrified. Treiber et al. (2015) noted that improvement towards the consumption of cleaner fuels would reduce energy poverty. Linear model investigations such as that of Ismail and Khembo (2015) predict a positive relationship between socio-economic development and energy fuels transition in South Africa. Howells et al. (2005) noted that a primary hindrance to facilitating energy transition in the country is the knowledge deficit in policymaking on factors that govern energy choices by households.

\section{Conceptual framework development}

This study, following the models discussed in the supplementary file, ${ }^{1}$ took into consideration both the energy ladder and the energy stacking hypotheses. Concerns on biomass fuels use and its effect on clean energy use have not been adequately analysed in the South African context (Howells et al., 2005), with very little empirical research exploring the appropriateness of energy choice models in the country's household sector. It is, however, noteworthy much empirical research has been conducted here with regard to the energy ladder (Alberts et al., 1997; Davis, 1998; Howells et al., 2006; Louw et al., 2008). There is limited research advancing the applicability of the energy stacking hypothesis, despite the work of Madubansi and Shackleton (2006); and Musango (2014), with objectives related to this hypothesis. The present study, therefore, comprehensively explored both the energy ladder and the energy stacking guidelines in the South African context. Uhunamure et al. (2017) can be recognised as one of the first researchers to consider both models for such a study. Households' fuel choice classification criteria of endogenous factors (household characteristics) and exogenous factors (external conditions) in Kowsari and Zerriffi (2011) guided the development of the conceptual framework for the empirical research (see Table 1).

The present study considered only the endogenous category. Two factors were considered from the economic characteristics and four factors from the non-economic characteristics.

\subsection{Economic characteristics}

The economic category was generally considered to be a primary influence on households' energy choice. The income and expenditure factor were sampled in the empirical research. Overemphasising income or expenditure as a measurement of wealth in determining a household's fuel choice is unclear, as in countries such as South Africa, a sig- 
Table 1: Household fuel choice factors (Kowsari and Zerriffi, 2011).

\begin{tabular}{|c|c|c|}
\hline Categories & Factors & Measuring aspect \\
\hline \multicolumn{3}{|c|}{ Endogenous factors } \\
\hline Economic characteristics & $\begin{array}{l}\text { Income, expenditure and } \\
\text { landholding }\end{array}$ & $\begin{array}{l}\text { Endogenous characteristics reflect the cap- } \\
\text { abilities of households, behavioural attitudes, } \\
\text { preferences and experiences of households }\end{array}$ \\
\hline $\begin{array}{l}\text { Non-economic } \\
\text { characteristics }\end{array}$ & $\begin{array}{c}\text { Household size, gender, age, household } \\
\text { composition, education, labour } \\
\text { and information }\end{array}$ & \\
\hline $\begin{array}{l}\text { Behavioural and cultural } \\
\text { characteristics }\end{array}$ & $\begin{array}{c}\text { Preferences(e.g food taste), } \\
\text { practices, lifestyle, social status and } \\
\text { ethnicity }\end{array}$ & \\
\hline \multicolumn{3}{|c|}{ Exogenous factors } \\
\hline Physical environment & $\begin{array}{l}\text { Geographic location and climatic } \\
\text { condition }\end{array}$ & $\begin{array}{l}\text { Exogenous factors influence household } \\
\text { decisions about their energy system by affecting } \\
\text { available choices and incentives to choose one } \\
\text { energy technology or fuel over another. }\end{array}$ \\
\hline Policies & $\begin{array}{c}\text { Energy policy, subsidies and market } \\
\text { and trade policies. }\end{array}$ & \\
\hline $\begin{array}{l}\text { Energy supply } \\
\text { element }\end{array}$ & $\begin{array}{l}\text { Affordability, availability, accessibility } \\
\text { and reliability of energy supplies }\end{array}$ & \\
\hline $\begin{array}{l}\text { Energy device } \\
\text { characteristics }\end{array}$ & $\begin{array}{l}\text { Conversion efficiency, cost and payment } \\
\text { method and complexity of operation }\end{array}$ & \\
\hline
\end{tabular}

nificant proportion of households depend on free, government-subsidised energy. Research can choose to use either income or expenditure as a measurement of wealth, but appplication should be relative to its context (Elias et al., 2005).

\subsubsection{Income and setting}

Income was the first factor studied in as a significant determinant of energy fuel choice, through the energy ladder model. Early findings concurred that there is a significant association between income and households energy choice (Barnes et al., 1994, 1996; Pachauri \& Spreng, 2004; Wuyuan et al., 2008). Even though new findings emerged exploring more comprehensive approaches to factors influencing household fuel choice pattern, Whitfield (2006:143) pointed out the shortcomings in energy research to advance the understanding of household fuel choice significantly beyond the influence of incomes. Van der Kroon et al. (2013) found that the placement of a household in the environment would typically determine the level of opportunity and possible income level.

\subsubsection{Expenditure}

Davis (1998) and Heltberg (2005) used expenditure instead of income in measuring economic influence on households' energy fuel choice. Low- and highincome households differ in energy spending as:

- the price of modern fuels, as well as their transaction cost, is usually high;

- income for low-income households is typically too low to accommodate payments associated with modern energy systems; and
- low-income households have an uncertain income source to accommodate regular spending required by modern energy sources.

A household's expenditure of fuel will depend on the unit price of the fuel demanded (Schlag \& Zuzarte, 2008:10). As a rise in a household income will enable its capacity to switch to more sustainable fuels, primary and useful energy consumption will also increase as well (Mestl \& Eskeland, 2009). Link et al. (2012) highlighted that minimum wages influence reliance on biomass energy fuels. Rao and Reddy (2013) maintained that household incomes derived from wages or salaries had a positive impact on the probability of using cleaner fuels. Van der Kroon (2013) found that a household's capital determined the fuel type relied on.

\subsection{Non-economic characteristics}

In early household fuel choice studies, the economic factor was the only one used to capture patterns of household fuel-switching through the aid of the energy ladder. However, non-economic elements later gained momentum, based on the concept of energy transition. Campbell et al. (2003) determined that income continued to be the most recommended determinant of fuel choice and the world is gradually heading to a dichotomy in which norms such as wealthier households being able to adopt modern fuels while poorer oness are increasingly forced to choose biomass will be irrelevant. The present empirical study considered the following household categories: size, education and gender. 


\subsubsection{Household size}

Kowsari and Zerriffi (2011) pointed out that household size determined the amount of energy consumed by a household. Household size indirectly influences households to practise both energy switching and energy stacking behaviours. Ado (2016) articulates household size to significantly affect the use of energy fuel types. The size of a household will influence fuel transition because large ones tend to practise energy stacking more than smaller ones.

\subsubsection{Education}

Link et al. (2012) asserted that education influenced energy fuel transition in two ways. Firstly, schooling limits the labour force for fuel acquisition activities such as wood collection, possibly leading to a tendency to adopt fuels requiring no acquisition efforts, such as paraffin and gas. Secondly, education can initiate change by providing knowledge about the dangers that biomass energy pose to health and the environment. Schlag and Zuzarte (2008:14) highlight that a large proportion of the global population, especially sub-Saharan Africans, lack significant tutelage on consumers fuel choice theory. Thus, some informal education on fuels will greatly impact on households' fuel preferences. Prasad (2008) highlighted the need for people to be well informed, and thus empowered, at household level about the advantages of cleaner energy and the shortcomings of biomass fuels. According to the theory of cognitive dissonance, individuals strive for consistency between their knowledge and behavioural attitudes (Kowsari \& Zerriffi, 2011). Whitfield (2006:143) mentioned that information education and social learning could be used to influence households energy fuels adoption significantly. Educational level will affect households' disposition to adopt modern fuels (Musango, 2014).

\subsubsection{Gender}

Patriarchal societies generally expect women to perform the majority of household tasks, such as cooking and washing. Gender can immensely influence fuel choice. A household where a male is the primary income earner and the main decision-maker might neglect the importance of the costs and benefit of clean cooking fuels (Schlag \& Zuzarte, 2008:13-15). Treiber (2015) concurred that culture and tradition can influence women ignoring modern energy technologies. It was found that women preferred preparing chapattis using charcoal and fuelwood as this was less time consuming, given constant and controllable heat. The cooking process involved traditional pots and biomass fuel, which influenced the taste (Treiber, 2015). Van der Kroon et al. (2013) found that women and children are most involved in collecting wood in most South East Asian countries. Balmer (2007) maintained that gender roles referred to the different tasks individuals performed; in households it means a division of labour in which different obligations are assigned to men and women.

\subsection{Household activities and energy use in the South African context}

The empirical research considered that certain fuels are mostly utilised for a particular household activity in the South African context. Electricity was the only energy type that households universally used for various activities such as cooking, lighting and heating. Use of LPG is mainly limited to cooking, solar energy to water heating. Direct utilisation of biomass fuel types (coal, wood and charcoal) by households includes for heating and cooking (Musango, 2014). Research on energy transition shows that most households' basic energy demand is for heating, cooking and lighting and fuel choice mostly relates to these (IEA, 2006:369). It is necessary to address these together for a realistic approach to household energy analysis (Kowsari \& Zerriffi, 2011) and they were what the present study focused on.

\section{Methodology}

The study considered households in the North West and Gauteng provinces of South Africa. Gauteng because of its level of urban growth and being the country's nucleus of social development. North West province was selected as a developing province, to represent the country's spatial geography. Pretoria and Johannesburg were the target sample cities in Gauteng, and Mafikeng and Potchefstroom in the North West.

A purposive-convenience sampling technique was used. Actual data gathering utilised the quota sampling guidelines. Purposive-convenience sampling involves targeting participants at random. Purposive targeting was employed to find mostly income earners considered to be the financial nucleus in providing households' day-to-day needs. Convenience sampling meant gathering data from households based on their availability and willingness to participate in the study. The quota sampling guideline was used to target households from identified zones from sample cities. The demographics are mostly in clusters where an urban city has an outskirt settlement - usually referred to as a township. These townships reflect underdeveloped characteristics as compared with central city settlements with more sustainable development tendencies. The aim was to identify low-income and highincome residential groups, ensuring that enough participants from both groups were considered. Table 2 presents a description of sampled groups, Table 3 shows the income brackets.

This paper is part of a larger project aimed at developing a framework for sustainable energy 
Table 2: A description of sampled groups.

\begin{tabular}{lcc}
\hline City & Quotas & $\begin{array}{c}\text { Income rank } \\
\text { status }\end{array}$ \\
\hline Mafikeng quota (A) & Riviera Park & High \\
Mafikeng quota (B) & Extension 36 & Low \\
Potchefstroom quota (A) & Potchefstroom & High \\
Potchefstroom quota (B) & Ikageng & Low \\
Pretoria (A) & Pretoria North & High \\
Pretoria (B) & Soshanguve & Low \\
Johannesburg (A) & Auckland Park & High \\
Johannesburg (B) & Soweto & Low \\
\hline
\end{tabular}

development in South Africa. The data collection employed closed-ended questionnaires with defined categories for examining the effect of electricity supply and consumption in the domestic sector and related electricity consumer behaviours. Questions were strictly dichotomous, with participants ticking "yes" or "no" on the options that relate to their practised fuel choice behaviours. In total, 400 households were given questionnaires, but just 323 responded.

\section{Data analysis and results}

The International Business Machines (IBM) Statistical Package for Social Sciences (SPSS) statistics version 24.0.0 was used in analysing data (IBM SPSS, 2016). A test for reliability was conducted on the data by estimating the Cronbach Alpha, which measures the internal consistency of responses and indicates the level to which participants' opinions are relative on scale. For an exploratory study, reliability measured by Cronbach's Alpha of $>0.5$ and $<0.7$ is good, and $>0.7$ gives excellent reliability. The Cronbach Alpha obtained was 0.74, implying that there was a sufficient internal consistency from acquired data. The Chi-square test was used to identify if an association existed between sampled groups through the Cramer's V. The aim was to determine the existence of equality between the two categorical (groups). A Cramer value $>0.1<0.3$ indicates small, $>0.3<0.5$ medium and $>0.5$ large associations between groups. The $\mathrm{p}$ values are also presented to confirm the validity of results. It is, however, not relevant for this paper as the research aimed at establishing practical significant differences among sample groups, rather than statistical differences.

\subsection{Influence of income on energy fuel choice}

The criteria used in this factor determinant involved sampling participants based on quotas within the target sample demographics. The investigation also reflected that groups' income status was relative to sampled income brackets similar to Makonese et al. (2018). The income profile of sampled groups is shown in Table 3.

The results indicate that sampled areas from townships on average comprised households with lower income brackets compared with those from main town zones. Analysis considered grouping all settlements with similar income status to perform a general analysis based on each of the classified income ranks (high- and low-income groups).

Table 4 shows the results for income groups' use of electricity for lighting, cooking and heating. The Cramer's V differs only marginally within income groups in the use of electricity for cooking of 0.13 and heating of 0.21 . Results indicate that $95.8 \%$ of households from the high-income group and $94.3 \%$ of low-income group used electricity for lighting in general. Furthermore, results indicate that income influences household's use of electricity for cooking and heating. Most high-income earners use electricity for cooking at $95.8 \%$ and heating at $79.1 \%$. Low-income earners use electricity less for cooking at $77.6 \%$ and heating at $71.5 \%$.

Table 5 reflects the results for income groups' use of LPG. The Cramer's V of 0.21 indicates a zero difference within income groups for the use of LPG for cooking and heating. Results reveal that highincome households tended to use gas at $35.2 \%$ as an alternative cooking fuel compared with $16.5 \%$ of low-income groups. Low-income groups tend to use paraffin for cooking at $15.2 \%$ compared with high-income households at $3 \%$.

Table 6 presents results for solar water heating. High-income households tended to utilise solar

Table 3: A description of the income profile of sampled groups.

\begin{tabular}{lcccccc}
\hline Groups & $\begin{array}{c}\text { Total } \\
\text { participants }\end{array}$ & $>15000$ & $15001-25000$ & $25001-34000$ & $34001-46000$ & $>46000$ \\
\hline Soweto & 49 & 38 & 5 & 6 & 0 & 0 \\
Extension 36 & 50 & 43 & 7 & 0 & 0 & 0 \\
Ikageng & 9 & 7 & 3 & 0 & 0 & 0 \\
Soshanguve & 50 & 33 & 8 & 9 & 0 & 0 \\
Rivira Park & 49 & 0 & 11 & 33 & 5 & 0 \\
Potcheftroom & 15 & 0 & 3 & 6 & 6 & 0 \\
Auckland Park & 50 & 0 & 0 & 8 & 24 & 18 \\
Pretoria North & 51 & 0 & 0 & 14 & 29 & 8 \\
\hline
\end{tabular}


Table 4: Use of electricity by income (ZAR/month).

\begin{tabular}{|c|c|c|c|c|c|c|}
\hline \multirow[t]{2}{*}{ Description } & \multicolumn{2}{|c|}{ High-income } & \multicolumn{2}{|c|}{ Low-income } & \multicolumn{2}{|c|}{ Cramer's V } \\
\hline & Yes & No & Yes & No & $P$ values & Effect \\
\hline \multicolumn{7}{|c|}{ Electricity use for lighting } \\
\hline Frequency & 158 & 7 & 149 & 9 & 0.05 & 0.03 \\
\hline Percentage & 95.8 & 4.2 & 94.3 & 5.7 & & \\
\hline \multicolumn{7}{|c|}{ Electricity use for cooking } \\
\hline Frequency & 139 & 19 & 128 & 37 & 0.01 & 0.13 \\
\hline Percentage & 95.8 & 5.7 & 77.6 & 22.4 & & \\
\hline \multicolumn{7}{|c|}{ Electricity use for heating } \\
\hline Frequency & 125 & 33 & 118 & 47 & 0.05 & 0.21 \\
\hline Percentage & 79.1 & 20.9 & 71.5 & 28.5 & & \\
\hline
\end{tabular}

Table 5: Use of liquefied petroleum gas and paraffin by income.

\begin{tabular}{|c|c|c|c|c|c|c|}
\hline \multirow[t]{2}{*}{ Description } & \multicolumn{2}{|c|}{ High-income } & \multicolumn{2}{|c|}{ Low-income } & \multicolumn{2}{|c|}{ Cramer's V } \\
\hline & Yes & No & Yes & No & $P$ values & Effect \\
\hline \multicolumn{7}{|c|}{ Gas use for cooking } \\
\hline Frequency & 58 & 107 & 26 & 132 & $<0.001$ & 0.21 \\
\hline Percentage & 35.2 & 64.8 & 16.5 & 83.5 & & \\
\hline \multicolumn{7}{|c|}{ Paraffin use for cooking } \\
\hline Frequency & 5 & 160 & 24 & 134 & $<0.001$ & 0.21 \\
\hline Percentage & 3 & 97 & 15.2 & 84.4 & & \\
\hline
\end{tabular}

Table 6: The use of solar water heater by income.

\begin{tabular}{lcccccc}
\hline Description & \multicolumn{2}{c}{ High-income } & \multicolumn{2}{c}{ Low-income } & \multicolumn{2}{c}{ Cramer's V } \\
\hline & Yes & No & Yes & No & P values & Effect \\
\hline Frequency & 40 & 125 & 16 & 142 & 0.001 & 0.26 \\
Percentage & 24.2 & 75.8 & 10.1 & 89.9 & & \\
\hline
\end{tabular}

Table 7: Use of traditional fuels (biomass) by income.

\begin{tabular}{|c|c|c|c|c|c|c|}
\hline \multirow[t]{2}{*}{ Description } & \multicolumn{2}{|c|}{ High-income } & \multicolumn{2}{|c|}{ Low-income } & \multicolumn{2}{|c|}{ Cramer's V } \\
\hline & Yes & No & Yes & No & $P$ values & Effect \\
\hline \multicolumn{7}{|c|}{ Use of wood for cooking } \\
\hline Frequency & 9 & 156 & 65 & 93 & $\square 0.001$ & 0.34 \\
\hline Percentage & 5.5 & 94.5 & 42 & 58 & & \\
\hline \multicolumn{7}{|c|}{ Use of wood for heating } \\
\hline Frequency & 20 & 145 & 28 & 130 & 0.05 & 0.07 \\
\hline Percentage & 12.1 & 87.9 & 17.7 & 82.3 & & \\
\hline \multicolumn{7}{|c|}{ Use of coal for cooking } \\
\hline Frequency & 6 & 152 & 118 & 47 & 0.05 & 0.53 \\
\hline Percentage & 4 & 96 & 72 & 28 & & \\
\hline \multicolumn{7}{|c|}{ Use of coal for heating } \\
\hline Frequency & 12 & 146 & 15 & 150 & 0.05 & 0.02 \\
\hline Percentage & 7.6 & 92.4 & 9.1 & 90.9 & & \\
\hline
\end{tabular}

water heaters at $24.2 \%$ as an alternative energy source for heating compared with $10.1 \%$ of lowincome groups. The use of solar within the income groups had an effect size of 0.26 tending towards medium. Cramer's $\mathrm{V}$ indicate that there is a small association between income and the use of solar water heaters.
Table 7 presents results on households' use of energy fuels with biomass. In general, Cramer's V reflect that there were medium differences within income groups for the use of wood for cooking at 0.34 and large differences for the use of coal for cooking at 0.53 . The results reflect that low-income households tended to use wood more for cooking at 
$42 \%$ compared with high-income households at $5.5 \%$. Low-income groups also used coal significantly for cooking at $72 \%$. High-income groups tended to not use coal for cooking, at only $4 \%$.

\subsection{Expenditure}

Expenditure on energy was also tested to determine the influence of spending power on households' energy choice. Participating households from the two sampled groups had to indicate their monthly spending on electricity on a scale ranging from below ZAR 200 to above ZAR 300. The aim was to determine the spending disparity on electricity within the sampled household groups. Table 8 presents the results for households spending on electricity, showing that high-income households spent most, with a larger proportion of them at $81.1 \%$ spending above ZAR 300 for electricity monthly. Low-income households at $27.8 \%$ spent less than ZAR 300, while $52.5 \%$ spent less than ZAR 200. This implies that the proportion of income devoted for electricity spending was small for low income households compared with high-income households.

\subsection{Household size}

Household size was a significant influence on energy choice. Table 9 presents results for household size effect on electricity for lighting, cooking and heating. Cramer's V reflect small differences for household size and use of electricity for cooking $(0.15)$ and heating $(0.18)$ but not lighting $(0.08)$.
Table 8: Expenditure per income groups in rands.

\begin{tabular}{|c|c|c|c|c|}
\hline Description & $<200$ & $<300$ & $>300$ & Total \\
\hline \multicolumn{5}{|c|}{ High income group } \\
\hline Frequency & 11 & 20 & 133 & 164 \\
\hline Percentage & 6.7 & 12.2 & 81.1 & 100 \\
\hline \multicolumn{5}{|c|}{ Low income group } \\
\hline Frequency & 83 & 31 & 44 & 158 \\
\hline Percentage & 52.5 & 19.6 & 27.9 & 100 \\
\hline
\end{tabular}

Table 10 presents the influence of household size on the use of LPG for cooking. Households with more members tended to utilise LPG for cooking. Cramer's V reflected small differences between household size and household use of paraffin (0.14); and gas fuel (0.13) for cooking. Families with 1 to 3 members used paraffin less for cooking $(4.5 \%)$, compared with households with 4 to 6 members (13.1\%), and 7 and more members $(11.8 \%)$. Households with 1 to 3 members also used less gas fuel for cooking $(22.3 \%)$ compared with households with 4 to 6 members $(26.3 \%)$ and at least 7 members (41.8\%).

Table 11 presents results for household size influence on the use of coal and wood for cooking and heating, indicating that household size was not significant here. For instance, the use of wood for heating when the frequency of participants and percentages obtained are compared reflected that household size with 1 to 3 members (14.1\%) and 4

Table 9: Household size influence on the use of electricity for lighting, cooking and heating.

\begin{tabular}{|c|c|c|c|c|c|c|}
\hline No. of members & Measurements & Yes & No & Total & $P$ value & Effect size \\
\hline \multicolumn{7}{|c|}{ Use of electricity for lighting } \\
\hline \multirow[t]{2}{*}{$1-3$} & Frequency & 128 & 2 & 130 & 0.05 & 0.18 \\
\hline & Percentage & 98.5 & 1.5 & 100 & & \\
\hline \multirow[t]{2}{*}{$4-6$} & Frequency & 148 & 8 & 156 & & \\
\hline & Percentage & 94.9 & 5.1 & 100 & & \\
\hline \multirow[t]{2}{*}{$>7$} & Frequency & 29 & 5 & 34 & & \\
\hline & Percentage & 85.3 & 14.7 & 100 & & \\
\hline \multicolumn{7}{|c|}{ Use of electricity for cooking } \\
\hline \multirow[t]{2}{*}{$1-3$} & Frequency & 47 & 78 & 125 & 0.021 & 0.15 \\
\hline & Percentage & 37.6 & 62.4 & 10 & & \\
\hline \multirow[t]{2}{*}{$4-6$} & Frequency & 61 & 94 & 155 & & \\
\hline & Percentage & 39.4 & 60.6 & 100 & & \\
\hline \multirow[t]{2}{*}{$>7$} & Frequency & 19 & 12 & 31 & & \\
\hline & Percentage & 61.3 & 38.70 & 100 & & \\
\hline \multicolumn{7}{|c|}{ Use of electricity for heating } \\
\hline \multirow[t]{2}{*}{$1-3$} & Frequency & 102 & 28 & 130 & 0.03 & 0.08 \\
\hline & Percentage & 78.5 & 21.5 & 100 & & \\
\hline \multirow[t]{2}{*}{$4-6$} & Frequency & 116 & 40 & 156 & & \\
\hline & Percentage & 74.40 & 25.60 & 100 & & \\
\hline \multirow[t]{2}{*}{$>7$} & Frequency & 23 & 11 & 34 & & \\
\hline & Percentage & 67.60 & 32.40 & 100 & & \\
\hline
\end{tabular}


Table 10: Household size influence on the use of liquefied petroleum gas and paraffin for cooking.

\begin{tabular}{|c|c|c|c|c|c|c|}
\hline No. of members & Measurements & Yes & No & Total & $P$ value & Effect size \\
\hline \multicolumn{7}{|c|}{ Use of paraffin for cooking } \\
\hline \multirow[t]{2}{*}{$1-3$} & Frequency & 7 & 149 & 130 & 0.03 & 0.14 \\
\hline & Percentage & 4.5 & 95.5 & 100 & & \\
\hline \multirow[t]{2}{*}{$4-6$} & Frequency & 17 & 113 & 156 & & \\
\hline & Percentage & 13.1 & 86.9 & 100 & & \\
\hline \multirow{2}{*}{$>7$} & Frequency & 4 & 30 & 34 & & \\
\hline & Percentage & 11.8 & 88.2 & 100 & & \\
\hline \multicolumn{7}{|c|}{ Use of gas for cooking } \\
\hline \multirow[t]{2}{*}{$1-3$} & Frequency & 29 & 101 & 130 & 0.06 & 0.13 \\
\hline & Percentage & 22.3 & 77.7 & 100 & & \\
\hline \multirow[t]{2}{*}{$4-6$} & Frequency & 41 & 115 & 156 & & \\
\hline & Percentage & 26.3 & 73.7 & 100 & & \\
\hline \multirow[t]{2}{*}{$>7$} & Frequency & 14 & 20 & 34 & & \\
\hline & Percentage & 41.2 & 58.8 & 100 & & \\
\hline
\end{tabular}

Table 11: Household size influence on the use of biomass for cooking and heating.

\begin{tabular}{|c|c|c|c|c|c|c|}
\hline No. of members & Measurements & Yes & No & Total & $P$ value & Effect size \\
\hline \multicolumn{7}{|c|}{ Use of wood for cooking } \\
\hline \multirow[t]{2}{*}{$1-3$} & Frequency & 22 & 134 & 156 & 0.05 & 0.09 \\
\hline & Percentage & 14.1 & 85.9 & 100 & & \\
\hline \multirow[t]{2}{*}{$4-6$} & Frequency & 17 & 113 & 130 & & \\
\hline & Percentage & 13.1 & 86.9 & 10 & & \\
\hline \multirow[t]{2}{*}{7} & Frequency & 8 & 26 & 34 & & \\
\hline & Percentage & 23.50 & 76.50 & 100 & & \\
\hline \multicolumn{7}{|c|}{ Use of coal for cooking } \\
\hline \multirow[t]{2}{*}{$1-3$} & Frequency & 6 & 150 & 156 & 0.29 & 0.09 \\
\hline & Percentage & 3.80 & 96.20 & 100 & & \\
\hline \multirow[t]{2}{*}{$4-6$} & Frequency & 8 & 122 & 130 & & \\
\hline & Percentage & 6.20 & 93.80 & 100 & & \\
\hline \multirow[t]{2}{*}{$>7$} & Frequency & 2 & 32 & 34 & & \\
\hline & Percentage & 5.90 & 94.10 & 100 & & \\
\hline \multicolumn{7}{|c|}{ Use of wood for heating } \\
\hline \multirow[t]{2}{*}{$1-3$} & Frequency & 22 & 134 & 156 & 0.13 & 0.11 \\
\hline & Percentage & 14.10 & 85.90 & 100 & & \\
\hline \multirow[t]{2}{*}{$4-6$} & Frequency & 17 & 113 & 130 & & \\
\hline & Percentage & 13.10 & 86.90 & 100 & & \\
\hline \multirow[t]{2}{*}{$>7$} & Frequency & 9 & 25 & 34 & & \\
\hline & Percentage & 26.50 & 73.50 & 100 & & \\
\hline \multicolumn{7}{|c|}{ Use of coal for heating } \\
\hline \multirow[t]{2}{*}{$1-3$} & Frequency & 10 & 146 & 156 & 0.26 & 0.09 \\
\hline & Percentage & 6.4 & 93.6 & 100 & & \\
\hline \multirow[t]{2}{*}{$4-6$} & Frequency & 12 & 118 & 130 & & \\
\hline & Percentage & 9.2 & 90.8 & 100 & & \\
\hline \multirow[t]{2}{*}{$>7$} & Frequency & 5 & 29 & 43 & & \\
\hline & Percentage & 14.7 & 85.3 & 100 & & \\
\hline
\end{tabular}

to $6(13.1 \%)$ displayed a similar pattern of wood use for heating.

Table 12 presents results for solar water heating.
Cramer's $\mathrm{V}$ indicate that there is no association between household size and the use of solar water heaters. 
Table 12: Household size influence on the use of solar water heating.

\begin{tabular}{lcccccc}
\hline No. of members & Measurements & Yes & No & Total & P value & Effect size \\
\hline $1-3$ & Frequency & 12 & 118 & 130 & 0.26 & 0.09 \\
& Percentage & 9.20 & 90.8 & 100 & & \\
$4-6$ & Frequency & 10 & 146 & 156 & & \\
& Percentage & 6.40 & 93.6 & 100 & & \\
& Frequency & 5 & 29 & 34 & \\
& Percentage & 14.7 & 85.3 & 320 & & \\
\hline
\end{tabular}

Table 13: Education's influence on the use of electricity for lighting, cooking and heating.

\begin{tabular}{|c|c|c|c|c|c|c|}
\hline Qualification level & Measurements & Yes & No & Total & P value & Effect size \\
\hline \multicolumn{7}{|c|}{ Use of electricity for lighting } \\
\hline \multirow[t]{2}{*}{ Grade 12 and below } & $v$ Frequency & 52 & 2 & 54 & 0.5 & 0.07 \\
\hline & Percentage & 96.3 & 3.7 & 100 & & \\
\hline \multirow[t]{2}{*}{ Diploma } & Frequency & 57 & 1 & 58 & & \\
\hline & Percentage & 98.3 & 1.7 & 100 & & \\
\hline \multirow[t]{2}{*}{ Degree } & Frequency & 86 & 5 & 91 & & \\
\hline & Percentage & 95.5 & 5.5 & 100 & & \\
\hline \multirow[t]{2}{*}{ Postgraduate } & Frequency & 106 & 7 & 113 & & \\
\hline & Percentage & 93.8 & 6.2 & 100 & & \\
\hline \multicolumn{7}{|c|}{ Use of electricity for cooking } \\
\hline \multirow[t]{2}{*}{ Grade 12 and below } & v Frequency & 37 & 17 & 34 & 0.18 & 0.12 \\
\hline & Percentage & 68.5 & 31.5 & 100 & & \\
\hline \multirow[t]{2}{*}{ Diploma } & Frequency & 48 & 10 & 58 & & \\
\hline & Percentage & 82.8 & 17.2 & 100 & & \\
\hline \multirow[t]{2}{*}{ Degree } & Frequency & 81 & 10 & 91 & & \\
\hline & Percentage & 89 & 11 & 100 & & \\
\hline \multirow[t]{2}{*}{ Postgraduate } & Frequency & 96 & 17 & 113 & & \\
\hline & Percentage & 85 & 15 & 100 & & \\
\hline \multicolumn{7}{|c|}{ Use of electricity for heating } \\
\hline \multirow[t]{2}{*}{ Grade 12 and below } & $v$ Frequency & 37 & 17 & 54 & 0.03 & 0.15 \\
\hline & Percentage & 68.50 & 31.50 & 100 & & \\
\hline \multirow[t]{2}{*}{ Diploma } & Frequency & 48 & 10 & 58 & & \\
\hline & Percentage & 82.8 & 17.2 & 100 & & \\
\hline \multirow[t]{2}{*}{ Degree } & Frequency & 86 & 5 & 91 & & \\
\hline & Percentage & 95.5 & 5.5 & 100 & & \\
\hline \multirow[t]{2}{*}{ Postgraduate } & Frequency & 96 & 17 & 113 & & \\
\hline & Percentage & 85 & 15 & 100 & & \\
\hline
\end{tabular}

\subsection{Education}

The opinions of participants were assessed by evaluating the influence of primary income earners' educational levels on the household's fuel choice. Table 13 presents results for electricity use for lighting, cooking and heating. Cramer's V reflected small differences for cooking (0.12) and heating (0.15). Participants with higher qualifications such as postgraduates (85\%) and degrees $(89 \%)$ used electricity mostly for cooking in comparison with participants who possessed a diploma $(82.8 \%)$ and grade 12 and below (68.5\%). Participants with higher qualifications, postgraduates $(85 \%)$ and degrees (95\%) used electricity mostly for heating compared with participants in possession of a diploma $(82.8 \%)$ and grade 12 and below (68.5\%).

Table 14 reflects results on the influence of educational level on the use of LPG and paraffin for cooking. It was found that there was an influence. Cramer's V indicated small-to-medium differences for the use of paraffin (0.19) and of gas (0.18). Participants with lower educational levels such as grade 12 and below (15.9\%) and diploma (11.1\%) used paraffin mostly for cooking compared with participants at higher educational levels: degree $(3.3 \%)$ and postgraduate (3.4\%). Participants with 
Table 14: Education's influence on the use of liquefied petroleum gas and paraffin for cooking.

\begin{tabular}{|c|c|c|c|c|c|c|}
\hline Qualification level $I$ & Measurements & Yes & No & Total & $P$ value & Effect size \\
\hline \multicolumn{7}{|c|}{ Use of paraffin for cooking } \\
\hline \multirow[t]{2}{*}{ Grade 12 and below } & w Frequency & 18 & 95 & 113 & 0.01 & 0.19 \\
\hline & Percentage & 15.9 & 84.10 & 100 & & \\
\hline \multirow[t]{2}{*}{ Diploma } & Frequency & 6 & 48 & 54 & & \\
\hline & Percentage & 11.1 & 88.80 & 100 & & \\
\hline \multirow[t]{2}{*}{ Degree } & Frequency & 3 & 88 & 91 & & \\
\hline & Percentage & 3.3 & 96.7 & 100 & & \\
\hline \multirow[t]{2}{*}{ Post-graduate } & Frequency & 2 & 56 & 58 & & \\
\hline & Percentage & 3.4 & 96.6 & 100 & & \\
\hline \multicolumn{7}{|c|}{ Use of gas for cooking } \\
\hline \multirow[t]{2}{*}{ Grade 12 and below } & w Frequency & 19 & 94 & 113 & 0.02 & 0.18 \\
\hline & Percentage & 16.8 & 83.2 & 100 & & \\
\hline \multirow[t]{2}{*}{ Diploma } & Frequency & 15 & 43 & 58 & & \\
\hline & Percentage & 25.9 & 74.1 & 100 & & \\
\hline \multirow[t]{2}{*}{ Degree } & Frequency & 25 & 66 & 91 & & \\
\hline & Percentage & 27.5 & 72.5 & 100 & & \\
\hline \multirow[t]{2}{*}{ Post-graduate } & Frequency & 21 & 33 & 54 & & \\
\hline & Percentage & 38.9 & 61.10 & 100 & & \\
\hline
\end{tabular}

higher qualifications postgraduate $(38.9 \%)$ and degrees $(27.5 \%)$, used gas more than those with lower qualifications: diploma (25.9\%) and grade 12 and below (16.8\%).

Table 15 reflects results on the influence of educational level on the use of biomass for cooking and heating. The Cramer's V reflect that medium differences existed for educational level and household use of wood for cooking (0.29) and heating (0.20). Participants with lower qualifications: grade 12 and below $(27.4 \%)$ and diploma (7.4\%), used wood for cooking than participants with higher qualifications: degree $(7.7 \%)$ and post-graduate $(3.4 \%)$. Results also reflect that participants with lower qualifications: grade 12 and below (23.9\%) and diploma $(14.8 \%)$, used wood for heating more than participants with higher qualifications: degree $(8.8 \%)$ and postgraduates $(6.9 \%)$.

These tendencies might follow these patterns because higher educational levels will tend to deter-

Table 15: Education's influence on biomass use for cooking and heating.

\begin{tabular}{|c|c|c|c|c|c|c|}
\hline Qualification level & Measurements & Yes & No & Total & $P$ value & Effect size \\
\hline \multicolumn{7}{|c|}{ Use of wood for cooking } \\
\hline \multirow[t]{2}{*}{ Grade 12 and below } & v Frequency & 31 & 82 & 113 & $<0.001$ & 0.29 \\
\hline & Percentage & 27.4 & 72.6 & 100 & & \\
\hline \multirow[t]{2}{*}{ Diploma } & Frequency & 4 & 50 & 54 & & \\
\hline & Percentage & 7.40 & 92.60 & 100 & & \\
\hline \multirow[t]{2}{*}{ Degree } & Frequency & 7 & 84 & 91 & & 1 \\
\hline & Percentage & 7.7 & 92.3 & 100 & & \\
\hline \multirow[t]{2}{*}{ Post-graduate } & Frequency & 2 & 56 & 58 & & \\
\hline & Percentage & 3.4 & 96.6 & 100 & & \\
\hline \multicolumn{7}{|c|}{ Use of coal for cooking } \\
\hline \multirow[t]{2}{*}{ Grade 12 and below } & v Frequency & 6 & 107 & 113 & 0.52 & 0.08 \\
\hline & Percentage & 5.3 & 94.7 & 100 & & \\
\hline \multirow[t]{2}{*}{ Diploma } & Frequency & 4 & 50 & 54 & & \\
\hline & Percentage & 7.4 & 92.6 & 100 & & \\
\hline \multirow[t]{2}{*}{ Degree } & Frequency & 3 & 55 & 58 & & \\
\hline & Percentage & 5.2 & 94.8 & 100 & & \\
\hline \multirow[t]{2}{*}{ Post-graduate } & Frequency & 2 & 89 & 91 & & \\
\hline & Percentage & 2.2 & 97.8 & 100 & & \\
\hline
\end{tabular}


Table 15: Education's influence on biomass use for cooking and heating.

\begin{tabular}{|c|c|c|c|c|c|c|}
\hline \multicolumn{7}{|c|}{ continued from previous page } \\
\hline Qualification level & Measurements & Yes & No & Total & P value & Effect size \\
\hline \multicolumn{7}{|c|}{ Use of wood for heating } \\
\hline \multirow{2}{*}{ Grade 12 and below } & Frequency & 27 & 86 & 113 & $<0.001$ & 0.20 \\
\hline & Percentage & 23.9 & 76.1 & 100 & & \\
\hline \multirow[t]{2}{*}{ Diploma } & Frequency & 8 & 46 & 54 & & \\
\hline & Percentage & 14.8 & 85.2 & 100 & & \\
\hline \multirow[t]{2}{*}{ Degree } & Frequency & 8 & 83 & 92 & & \\
\hline & Percentage & 8.8 & 91.2 & 100 & & \\
\hline \multirow[t]{2}{*}{ Post-graduate } & Frequency & 4 & 54 & 58 & & \\
\hline & Percentage & 6.9 & 93.1 & 100 & & \\
\hline \multicolumn{7}{|c|}{ Use of coal for heating } \\
\hline \multirow[t]{2}{*}{ Grade 12 and below } & Frequency & 6 & 102 & 108 & 0.31 & 0.09 \\
\hline & Percentage & 5.3 & 90.1 & 100 & & \\
\hline \multirow[t]{2}{*}{ Diploma } & Frequency & 9 & 82 & 101 & & \\
\hline & Percentage & 9.9 & 90.1 & 100 & & \\
\hline \multirow[t]{2}{*}{ Degree } & Frequency & 6 & 48 & 50 & & \\
\hline & Percentage & 11.1 & 88.9 & 100 & & \\
\hline \multirow[t]{2}{*}{ Post-graduate } & Frequency & 3 & 55 & 58 & & \\
\hline & Percentage & 5.2 & 94.8 & 100 & & \\
\hline \multicolumn{7}{|c|}{ Use of coal for heating } \\
\hline \multirow[t]{2}{*}{ Grade 12 and below } & Frequency & 6 & 102 & 108 & 0.31 & 0.09 \\
\hline & Percentage & 5.3 & 90.1 & 100 & & \\
\hline \multirow[t]{2}{*}{ Diploma } & Frequency & 9 & 82 & 101 & & \\
\hline & Percentage & 9.9 & 90.1 & 100 & & \\
\hline \multirow[t]{2}{*}{ Degree } & Frequency & 6 & 48 & 50 & & \\
\hline & Percentage & 11.1 & 88.9 & 100 & & \\
\hline \multirow[t]{2}{*}{ Post-graduate } & Frequency & 3 & 55 & 58 & & \\
\hline & Percentage & 5.2 & 94.8 & 100 & & \\
\hline
\end{tabular}

Table 16: Education's influence on solar water heating.

\begin{tabular}{lcccccc}
\hline Qualification level & Measurements & Yes & No & Total & P value & Effect size \\
Grade 12 and below Frequency & 2 & 111 & 113 & 0.05 & 0.16 \\
\multirow{4}{*}{ Diploma } & Percentage & 1.8 & 98.2 & 100 & & \\
\multirow{2}{*}{ Degree } & Frequency & 1 & 90 & 100 & \\
\multirow{4}{*}{ Post-graduate } & Percentage & 1.1 & 98.9 & 100 & \\
& Frequency & 3 & 51 & 54 & \\
& Percentage & 5.6 & 94.4 & 100 & \\
\hline
\end{tabular}

mine income, levels of comfort, and lifestyle.

The relationship between educational qualifications and the use of solar water heaters is presented in Table 16. The Cramer's V confirmed small differences for educational level and household use of solar water heaters (0.16). Participants with higher qualification: postgraduate $(8.6 \%)$ and degree $(5.6 \%)$ used more solar energy than those with lower qualifications: diploma (1.1\%) and grade 12 and below (1.8\%).

\subsection{Gender}

Gender assessment was made of the male and female participants' usage of different energy sources for domestic activities. Table 17 presents the results for lighting, cooking and heating. The Cramer's V reflects small differences for gender and the use of electricity for lighting (0.14) and cooking (0.16). Results indicate that male participants use electricity mostly for lighting $(98.1 \%)$, compared to females (92.2). Results also reflect that male partic- 
Table 17: The influence of gender on electricity use for lighting, cooking and heating.

\begin{tabular}{|c|c|c|c|c|c|c|}
\hline Gender & Measurements & Yes & No & Total & $P$ value & Effect size \\
\hline \multicolumn{7}{|c|}{ Use of electricity for lighting } \\
\hline \multirow[t]{2}{*}{ Male } & Frequency & 153 & 3 & 156 & 0.01 & 0.14 \\
\hline & Percentage & $98.10 \%$ & $1.90 \%$ & $100 \%$ & & \\
\hline \multirow[t]{2}{*}{ Female } & Frequency & 154 & 13 & 167 & & \\
\hline & Percentage & $92.20 \%$ & $7.80 \%$ & $100 \%$ & & \\
\hline \multicolumn{7}{|c|}{ Use of electricity for cooking } \\
\hline \multirow[t]{2}{*}{ Male } & Frequency & 65 & 91 & 156 & 0.01 & 0.16 \\
\hline & Percentage & $41.60 \%$ & $58.40 \%$ & $100 \%$ & & \\
\hline \multirow[t]{2}{*}{ Female } & Frequency & 63 & 104 & 167 & & \\
\hline & Percentage & $37.70 \%$ & $62.3 \% \%$ & 100 & & \\
\hline \multicolumn{7}{|c|}{ Use of electricity for heating } \\
\hline \multirow[t]{2}{*}{ Male } & Frequency & 121 & 35 & 156 & 0.34 & 0.05 \\
\hline & Percentage & $77.60 \%$ & $22.40 \%$ & $100 \%$ & & \\
\hline \multirow[t]{2}{*}{ Female } & Frequency & 122 & 45 & 167 & & \\
\hline & Percentage & $73.10 \%$ & $26.90 \%$ & $100 \%$ & & \\
\hline
\end{tabular}

Table 18: The influence of gender on liquefied petroleum gas and paraffin use for cooking.

\begin{tabular}{|c|c|c|c|c|c|c|}
\hline Gender & Measurements & Yes & No & Total & $P$ value & Effect size \\
\hline \multicolumn{7}{|c|}{ Use of paraffin for cooking } \\
\hline \multirow[t]{2}{*}{ Male } & Frequency & 39 & 117 & 156 & 0.27 & 0.1 \\
\hline & Percentage & 25 & 75 & 100 & & \\
\hline \multirow[t]{2}{*}{ Female } & Frequency & 47 & 120 & 167 & & \\
\hline & Percentage & 28.1 & 71.9 & 100 & & \\
\hline \multicolumn{7}{|c|}{ Use of gas for cooking } \\
\hline \multirow[t]{2}{*}{ Male } & Frequency & 45 & 111 & 156 & 0.26 & 0.11 \\
\hline & Percentage & 28.8 & 71.2 & 100 & & \\
\hline \multirow[t]{2}{*}{ Female } & Frequency & 39 & 128 & 167 & & \\
\hline & Percentage & 23.4 & 76.6 & 100 & & \\
\hline
\end{tabular}

ipants' use electricity most for cooking (41.6\%), compared to females $(37.7 \%)$.

Table 18 reflects the influence of gender on the use of LPG. The Cramer's V showed small differences for gender and the use of paraffin for cooking (0.1) and gas for cooking (0.1). Paraffin was more used for cooking by females $(28.1 \%)$ than males $(25 \%)$. Gas was used for cooking mostly by men $(28.8 \%)$ than by females $(23.4 \%)$. Inconsequential effect sizes were, however, reflected for gender influence on LPG use.

Table 19 presents the influence of gender on the use of biomass for cooking and heating. The Cramer's $\mathrm{V}$ indicated small differences for gender and the use of wood for cooking (0.14) and coal for cooking (0.12). Wood was used more for cooking by females $(30.5 \%)$ than by males $(12.2 \%)$. A noteworthy difference was recorded in the use of coal for cooking for female (10.8\%) and male (5.8\%).

Table 20 reflects results on the influence of gender on renewable energy use for heating. The Cramer's $\mathrm{V}$ reflect no significant differences for gender and the use of solar water heaters.

\section{Conclusions}

The research aimed to assess determinants of energy fuel choice in the South African household context by utilising the guidelines of the energy ladder and energy stacking hypotheses. Results were consistent with those of some previous studies, but some are unique to the South African context.

Findings reflected that high-income households tend to use more advanced energy sources of energy fuels than low-income ones in general. Highincome groups used more electricity for cooking and heating. However, electricity is used by all income groups primarily for lighting. Low-income households tend to use paraffin for cooking, compared with high-income households that tend to use more LP gas. Solar water heaters are more used by high-income households for heating. Low-income households tend to use wood fuel significantly for cooking and heating. Coal tends to be used by lowincome groups for cooking. Findings also reflect that monthly electricity expenditure above ZAR 300 is commoner with high-income households $(81.1 \%)$ than low-income ones $(27.8 \%)$. 
Table 19: The influence of gender on biomass use for cooking and heating.

\begin{tabular}{|c|c|c|c|c|c|c|}
\hline Gender & Measurements & Yes & No & Total & $P$ value & Effect size \\
\hline \multicolumn{7}{|c|}{ Use of wood for cooking } \\
\hline \multirow[t]{2}{*}{ Male } & Frequency & 19 & 137 & 156 & 0.06 & 0.14 \\
\hline & Percentage & 12.2 & 87.8 & 100 & & \\
\hline \multirow[t]{2}{*}{ Female } & Frequency & 51 & 116 & 167 & & \\
\hline & Percentage & 30.50 & 69.50 & 100 & & \\
\hline \multicolumn{7}{|c|}{ Use of coal for cooking } \\
\hline \multirow[t]{2}{*}{ Male } & Frequency & 6 & 161 & 167 & 0.26 & 0.12 \\
\hline & Percentage & 3.60 & 96.4 & 100 & & \\
\hline \multirow[t]{2}{*}{ Female } & Frequency & 56 & 100 & 156 & & \\
\hline & Percentage & 36. & 64 & 100 & & \\
\hline \multicolumn{7}{|c|}{ Use of wood for heating } \\
\hline \multirow[t]{2}{*}{ Male } & Frequency & 23 & 144 & 167 & 0.05 & 0.03 \\
\hline & Percentage & 13.8 & 86.2 & 100 & & \\
\hline \multirow[t]{2}{*}{ Female } & Frequency & 25 & 131 & 156 & & \\
\hline & Percentage & 16 & 84 & 100 & & \\
\hline \multicolumn{7}{|c|}{ Use of coal for heating } \\
\hline \multirow[t]{2}{*}{ Male } & Frequency & 9 & 147 & 156 & 0.10 & 0.09 \\
\hline & Percentage & 5.8 & 94.2 & 100 & & \\
\hline \multirow[t]{2}{*}{ Female } & Frequency & 18 & 149 & 167 & & \\
\hline & Percentage & 10.8 & 89.2 & 100 & & \\
\hline
\end{tabular}

Table 20: The influence of gender on solar water heating.

\begin{tabular}{lcccccc}
\hline Gender & Measurements & Yes & No & Total & P value & Effect size \\
\hline Male & Frequency & 19 & 137 & 156 & 0.42 & 0.07 \\
\multirow{3}{*}{ Female } & Percentage & 12.1 & 87.9 & 100 & & \\
& Frequency & 4 & 120 & 167 & & \\
& Percentage & 2.6 & 97.4 & 100 & & \\
\hline
\end{tabular}

Results reflect that household size will influence the use of energy for lighting, cooking and heating. Larger households tend to use LPG for cooking more than smaller ones. Household size has a limited influence on biomass use, except for wood for heating, and no influence on the use of solar energy for water heating. Results reflect that educational level correlate to household energy fuel choice. Household participants with higher educational qualification levels (postgraduates and degreed) have a greater tendency to use electricity for lighting, cooking and heating. Participants with lower academic qualifications (Diploma and grade 12 and below) use more paraffin for cooking while participants with higher qualifications tend more to use gas. For biomass, education greatly influences the use of woodfuel for both heating and cooking. Education has little impact on the use of solar energy for water heating.

As regards the influence of gender on energy choice, more male participants use electricity for lighting, cooking and heating than female ones. Males use gas fuel more for cooking while females use more paraffin. There were insignificant differ- ences in biomass use between females and men, except for wood in cooking. The results also showed that more male participants utilise solar energy for heating than female participants.

\section{References}

Adam, F. 2010. Free Basic Electricity: A better life for all. Earthlife Africa: Johannesburg.

Ado, A., Darazo, I. \& Babayo, M. 2016. Determinants of fuels stacking behaviour among households in Bauchi Metropolis. The Business and Management Review, 7 (3): 84-97.

Alberts, H., Moreira, C. \& Pérez, R. 1997. Firewood substitution by kerosene stoves in rural and urban areas of Nicaragua, social acceptance, energy policies, greenhouse effect and financial implications. Energy for Sustainable Development, 3(5):26-39.

Baldwin, S. 1986. Biomass stoves: engineering design, development, and dissemination. VITA and PU/CEES Report No. 224, Arlington, VA and Princeton, NJ.

Balmer, M. 2007. Energy poverty and cooking energy requirements: The forgotten issue in South African energy policy? Journal of Energy in Southern Africa, $18(3): 4-9$. 
Barnes, D. \& Floor, W. 1996. Rural energy in developing countries: a challenge for economic development. Annual Review of Energy and the Environment, 21:497-530.

Barnes, D., Dowd, J., Qian, L., Krutilla, K. \& Hyde, W. 1994. Urban energy transitions, poverty, and the environment: Understanding the role of the urban household energy in developing countries, World Bank, Industry and Energy Department, September Draft.

Campbell, B., Vermeulen, S., Mangono, J. \& Mabugu, R. 2003. The energy transition in action: urban domestic fuel choices in a changing Zimbabwe. Energy Policy, (31):553-562.

Davis, M. 1998. Rural household energy consumption: the effects of access to electricity evidence from South Africa. Energy Policy, (26):207-217.

Elias, R. \& David, V. 2005. Energy transitions in developing countries: A review of concepts and literature. Working paper \#40 June.

file://C:/Users/NWUUser/Documents/Energy\%20Tra nsitions.pdf [14 July 2017].

Elias, R. \& Victor, D. 2005. Energy Transitions in developing countries: A review of concepts and literature. Working Paper No. 40. Stanford, CA: Stanford University.

Ellingsen, A. 2010. Fuel or energy poverty, possible causes, effects and remedies. http://energymanagement.no/resources/2010\%20Fuel\%20or\%20energy\%20poverty, \%20possible\%20causes, $\% 20$ effects\% 20and\%20remedies.pdf [26 July 2017].

Gallachóir, B., Keane, M., Morrissey, E. \& O’Donnell, J. 2007. Using indicators to profile energy consumption and to inform energy policy in a university - a case study in Ireland. Energy and Buildings, 39:913922.

Gaunt, T. 2005. Meeting electrification's social objectives in South Africa, and implications for developing countries. Energy Policy, 33:1309-1317.

Goldemberg, J. 1996. Energy, environment and development. London: Earthscan.

Gordon, J. \& Hyman, J. 2012. The stoves are also stacked: Evaluating the energy Ladder, cookstove swap-out programs, and social adoption preferences in the cookstove literature. Journal of Environmental Investing, 3(1):17-41

Heltberg, R. 2004. Fuel switching: evidence from eight developing countries. Energy Economics, 26:869_ 887.

Hiemstra-van der Horst, G. \& Hovorka, A. 2008. Reassessing the energy ladder: Household energy use in Maun, Botswana. Energy Policy, 36(9):33333344

Hosier, R. \& Dowd, J. 1987. Household fuel choice in Zimbabwe: An empirical test of the energy ladder hypothesis. Resources and Energy, 9(4):347-361.

Howells, M., Alfstada, T., Victor, D., Goldstein, G. \& Remme, U. 2005. A model of household energy services in a low-income rural African village. Energy Policy, 33:1833-1851.

Howells, M., Victor, D., Gaunt, T., Rebecca, J., Alfstad, E. \& Alfstad, T. 2006. Beyond free electricity: The costs of electric cooking in poor households and a market-friendly alternative. Energy Policy, 34(17):3351-3358.

IBM Corp. Released 2016. IBM SPSS statistics for Windows, version 24.0. Armonk, NY: IBM Corp.

IEA (International Energy Agency). 2002. Part C: special issues arising from the world energy outlook. Available at: http://www.worldenergyoutlook.org/media/weowebsite/20081994/weo2002_part2.pdf [25 July 2017].

IEA (International Energy Agency). 2006. World energy outlook 2006. International Energy Agency (IEA), Paris.

Inglesi, R. 2010. Aggregate electricity demand in South Africa: Conditional forecasts to 2030. Applied energy, 87:197-204.

Ismail, Z. \& Khembo, P. 2015. Determinants of energy poverty in South Africa1. Journal of Energy in Southern Africa, 26 (3):66-78.

Jiang, L. \& O'Neill, B. 2004. The energy transition in rural China. International Journal of Glob Energy Issues, 21:2-26.

Johnson, M., Edwards, R., Morawska, L., Smith, K. \& Nicas, M. 2013. WHO indoor air quality guidelines: household fuel combustion review 3: Model for linking household energy use with indoor air quality. Available at: http://www.who.int/indoorair/guidelines/hhfc/Review_3. Pdf [17 July 2017].

Kowsari, R. \& Zerriffi, H. 2011. Three-dimensional energy profile: A conceptual framework for assessing household energy use. Energy Policy, 39(12):75057517.

Link, C., Axinn, W. \& Ghimire, D. 2012. Household energy consumption: Community context and the fuelwood transition. Social Science Research, 41:598-611.

Louw, K., Conradie, B., Howells, M. \& Dekenah, M. 2008. Determinants of electricity demand for newly electrified low-income African households. Energy Policy, 36:2812- 2818.

Madubansi, M. \& Shackleton, C. 2006. Changing energy profiles and consumption patterns following electrification in five rural villages, South Africa. Energy Policy, 34:4081-4092.

Makones. T., Ifegbesan, A. \& Rampedi, I. 2018. Household cooking fuel use patterns and determinants across Southern Africa: Evidence from the demographic and health survey data. Energy \& Environment, 29(1):29-48.

Masera, O. \& Navia, J. 1997. Fuel switching or multiple cooking fuels? Understanding inter-fuel substitution patterns in rural Mexican households. Biomass Bioenergy, 12(5):347-361.

Masera, O., Saatkamp, B. \& Kammen, D. 2000. From linear fuel switching to multiple cooking strategies: A critique and alternative to the energy ladder model. World Development, 28(12): 2083-103.

Mekonnen, A. \& Köhlin, G. 2008. Determinants of household fuel choice in major cities in Ethiopia. Environment for Development Discussion paper series. EfD DP 08-18.

Mestl, E. \& Eskeland, G. 2009. Richer and healthier, but not greener? Choices concerning household energy use in India. Energy Policy, 37:3009-3019. 
Muller, C. \& Yan, H. 2016. Household fuel use in developing countries: Review of theory and evidence. HAL Id: halshs-01290714. Available at: https://halshs.archives-ouvertes.fr/halshs-01290714 [17 July 2017].

Musango, J. 2014. Household electricity access and consumption behaviour in an urban environment: The case of Gauteng in South Africa. Energy for Sustainable Development, 23: 305-316.

Ogwumike, F., Ozughalu, U. \& Abiona, G. 2014. Household energy use and determinants: Evidence from Nigeria. International Journal of Energy Economics and Policy, 4(2):248-262.

Oparinde, A. 2010. Investigating the relationship between income, health and biomass consumption: A panel data analysis. Munich Personal Repec Archive. MPRA paper no. 39305. http://mpra.ub.unimuenchen.de/39305/.

Pachauri, S. \& Rao, N. 2014. Energy inequality: Policy note for IIASA-Alpbach Group. Available. at: https:/www.alpbach.org/wpcontent/uploads/2014/08 /Conceptual_note_on_Energy_Inequality.pdf [26 July 2017].

Pachauri, S. \& Spreng, D. 2004. Energy use and energy access in relation to poverty. Economic and Political Weekly, 39(3):271-278.

Pachauri, S., Van Ruijven, B., Nagai1, Y., Riahi1, K., Van Vuuren, D., Brew-Hammond, A. \& Nakicenovic, N. 2013. Pathways to achieve universal household access to modern energy by 2030. Environmental Research Letters, 8(024015):1-7.

Prasad, G. 2008. Energy sector reform, energy transitions and the poor in Africa. Energy Policy, 36:28062811.

Rao, M. \& Reddy, B. 2013. Variations in energy use by Indian households: an analysis of micro-level data. Energy, 32:143-153.

Rehfuess, E. 2006. Fuel for life: Household energy and health. Geneva: World Health Organisation. Available at: http://www.who.int/indoorair/publications/fuelforlife.pdf [27 June 2017].

Risseeuw, N. 2012. Household energy in Mozambique: A study on the socioeconomic and cultural determinants of stove and fuel transitions. Available at: http://www.ivm.vu.nl/en/Images/Risseeuw_Natasha __FINAL_THESIS_tcm234-352225.pdf [27 June 2017].

Sanga, G. \& Jannuzzi, G. 2005. Impacts of efficient stoves and cooking fuel substitution in family expenditures of urban households in Dar es Salaam, Tanzania. International Energy Initiative Energy Discussion Paper No. 2.59.1/05.

Taylor, Matthew, J., Michelle, J., Moran-Taylor, M., Castellanos, E. \& Elías, S. 2011. Burning for sustainability: Biomass energy, international migration, and the move to cleaner fuels and cookstoves in guatemala. Annals of the Association of American Geographers, 101 (4): 918-928.

Treiber, M., Grimsby, L. \& Aune, J. 2015. Reducing energy poverty through increasing choice of fuels and stoves in Kenya: Complementing the multiple fuel model. Energy for Sustainable Development, 27:54-62.
Uhunamure, S., Nethengwe, N. \& Musyoki, A. 2017. Driving forces for fuelwood use in households in the Thulamela municipality, South Africa. Journal of Energy in Southern Africa, 28(1): 25-34.

Van der Kroon, N., Brouwer, R. \& Van Beukering, P. 2013. The energy ladder: Theoretical myth or empirical truth? Results from a meta-analysis bianca. Renewable and Sustainable Energy Reviews, 20:504-513.

Whitfield, D. 2006. Household behaviour and energy demand: Evidence from Peru, in public policy. Massachusetts: Harvard.

Wuyuan, P., Zerriffi, H., Pan, J. 2008. Household level fuel switching in rural Hubei. Stanford. The Program on Energy and Sustainable Development (PESD). Stanford University, USA. 